\title{
BIOMARKERS OF COAGULATION ACTIVATION IN CHILDREN WITH SICKLE CELL DISEASE
}

Shimaa S. Dawood ${ }^{1}$, Mohamed A. Soliman', Mona K. El-Ghamrawy ${ }^{3}$, and Hisham A. Ismail $^{1}$

${ }^{1}$ Molecular Diagnostics Department, Genetic Engineering and Biotechnology Research Institute (GEBRI), Sadat City University, Egypt

${ }^{2}$ Clinical Pathology Department, Faculty of Medicine, Menoufiyia University, Egypt.

${ }^{3}$ Peditric Department, Kasr Al-Ainy School of Medicine, Cairo University, Cairo, Egypt Corresponding author-mail: shimaa2785166@yahoo.com and shimaa2785166@ gmail.com

\begin{abstract}
\section{Introduction}

Sickle cell disease (SCD) is the first human inherited disease shown to be linked to a single amino acid mutation caused by a single nucleotide substitution in a known gene (Kato, 2015). Glutamic acid is replaced by valine on the $\beta$ globin chain of hemoglobin molecule results in production of an abnormal sickle hemoglobin $(\mathrm{HbS}), \mathrm{HbS}$ polymerized into rigid fibers when deoxygenated that cause deformation of the erythrocytes

(Elias et al., 2012).

Sickle cell abnormal shape causes various complications in patients with $\mathrm{SCD}$, haemolysisand Vaso-occlusion are the most common complications. Haemolysis results in high free hemoglobin levels within circulation which causes reduction in Nitric oxide (NO), a vasodilator, bioavailability and contributing to the vasoocclusivion(Elias et al., 2012). SCD is associated with increased procoagulant factor as circulating tissue factor (TF), increased markers of thrombin generation, decreased levels of natural anticoagulant proteins, and evidence of platelet and fibrinolytic system activation (Key et al., 1998; Nishanket
\end{abstract}

Sickle cell disease (SCD) is a multisystem disease, characterized by its multiphenotypic diversity although being a disease caused by a single nucleotide substitution.In the present study, we measured biomarkers of coagulation activation in children with SCD. The study was performed on 50 Egyptian children with SCD and 41 age- and sex-matched controls. Complete blood picture (CBC), International normalized ratio (INR)and Partial thromboplastin time (PTT) levels were measured. Thrombin-antithrombin (TAT) plasma levels was estimated by enzyme-linked immunosorbent assay (ELISA). A statically significant increase in all of INR, PTT and TAT plasma levels were detected. We agree with the previous studies that children with SCD exhibit a hypercoagulable state.

Key words: Sickle cell disease - Hypercoagulability- Thrombin-Antithrombin.

al., 2013).

Exposure of phosphatidylserine (PS) on sickle cell surface functions as a recognition signal for cell removal during apoptosis of nucleated cells, a docking site for enzymatic complexes involved in coagulation and anticoagulation pathways and alters the adhesive properties of sickle RBC (Stowellet al., 2009; Uchida et al., 2011; Artemenkoet al., 2016). Over expression of TF on the surface of each platelet, endothelial cells and circulating microparticles (MP), derived from endothelial cells and monocytes. MP, small membrane-derived vesicles released by cells following activation or apoptosis, may be derived from RBC, platelets, endothelial cells and monocytes according to its origin they express TF or PS on their surfaces on both cases a state of coagulation activation occurs (Shetet al., 2003). In our study we investigate the hypercoagulable state in Egypchildren with SCD.

\section{Materials and methods Study subjects}

This study included fifty children (24 males and 26 females) with SCD, their ages range from 2 to 18 years. Patients were 
diagnosed as SCD patients according to hemoglobin electrophoresis pattern. Referring patients were invited to participate in the study during their regular follow-up visits in Pediatric Hematology Clinic, New Children Hospital, Cairo University. Patients participated after informed consents were freely obtained from their guardians. Forty one age- and sex-matched healthy children free from hematological disorders were studied as a control group.Our study was approved by the Ethical Committee of Kasr Al-Ainy School of Medicine, Cairo University.

\section{Blood sampling}

Venous blood samples were withdrawn from both patients and control under aseptic conditions and divided into two tubes, ethylenediaminetetraacetic acid (K-EDTA) tube for complete blood cell (CBC) count, and other sodium citrated tube for coagulation profile.

\section{Hematological analysis}

CBC was performed by PENTRA-80 automated blood cell analyzer (ABX Diagnostics, Montpellier, France).

\section{Coagulation profile}

Plasma was obtained by centrifugation of citrated tube at $4^{\circ} \mathrm{C}$ for 20 minutes at 2,200 $\mathrm{g}$ (within $15 \mathrm{~min}$ after blood collection). International Normalized Ratio (INR) and Partial thromboplastin time (PTT) were tested by Stago fully automated instrument (STA Compact; DiagnosticaStago S.A.S., Gennevilliers, Paris, France) using commercial reagents and following the standard procedures for each test [thromboplastin reagent (STA Neoplastine CI Plus 10) for prothrombin time (PT) and STA - C.K. PREST 5 for activated partial thromboplastin time (APTT)].

For TAT measurement, Citrated plasma was stored at $-20^{\circ} \mathrm{C}$ for AT antigen measurement which quantified by thrombin-antithrombin complex-derived human enzyme-linked immunosorbent assay kit (AbCam China, Shanghai, China).

\section{Results}

In the present study, 50 children with sickle cell disease and 41 free from hematological disorders individuals as control group were enrolled.In Table 1 both control and SCD subjects' demographic parameters were illustrated.

Table 1.Demographic parameter of SCD patients and control subjects.

\begin{tabular}{llll}
\hline Parameter & Control $\mathbf{n = 4 1}$ & SCD $\mathbf{n}=\mathbf{5 0}$ & $\mathbf{p}$-value \\
\hline Gender $($ Male/female $)$ & $15 / 26$ & $24 / 26$ & NS \\
Age & $9 \pm 5$ & $9 \pm 6$ & NS \\
Mean \pm SD & & &
\end{tabular}

Significance $p<0.05$, no significance (NS)

Hematological parameters in both SCD patients and control subjects were shown in Table 2. In which, highly statically significant reduction in red blood cells (RBCs) count, hemoglobin ( $\mathrm{Hb})$ concentration and hematocrit (HCT) levels $(p<0.001)$ with negative correlation in RBCs count $(r=-0.791, \quad \mathrm{p}<0.001), \quad \mathrm{Hb}$ concentration $(r=-0.791, \quad \mathrm{p}<0.001)$ and HCT $(r=-0.791, p<0.001)$ were observed in SCD patients.

Where a remarkable increase in $\mathrm{RBCs}$ indices; mean corpuscular volume (MCV) $(\mathrm{p}<0.01)$, mean corpuscular hemoglobin
$(\mathrm{MCH})(\mathrm{p}<0.001)$ and mean corpuscular hemoglobin concentration (MCHC) levels $(\mathrm{p}<0.01)$ with positive 0.379 , correlation $(\mathrm{r}=0.314, \mathrm{p}<0.01 ; \mathrm{r}=$ $\mathrm{p}<0.001 ; \quad \mathrm{r}=0.268, \quad \mathrm{p}<0.01$, respectively) were detected in SCD patients compared with controls. Significant increase in WBCs $(\mathrm{p}<0.01)$, monocytes $(p<0.001)$ and granulocytes count $(p<0.01)$ in SCD patients than those health control with positive correlation $(\mathrm{r}=0.396$, $\mathrm{p}<0.001 ; \mathrm{r}=0.640, \mathrm{p}<0.001 ; \mathrm{r}=0.357$, $\mathrm{p}<0.01$, respectively) was observed. 
Table 2. Hematological parameters of SCD patients and control subjects.

\begin{tabular}{|l|l|l|l|l|}
\hline Parameters & $\begin{array}{l}\text { Control } \\
(\mathbf{n = 4 1})\end{array}$ & SCD $(\mathbf{n = 5 0})$ & p-value & $\begin{array}{l}\text { Correlation } \\
\text { SCD }\end{array}$ \\
\hline $\mathrm{RBC}\left(10^{6} / \mu \mathrm{l}\right)$ & $4.61 \pm 0.34$ & $2.85 \pm 0.87$ & $<0.001$ & $\begin{array}{l}\mathrm{r}=-0.791 \\
\mathrm{p}<0.001\end{array}$ \\
\hline $\mathrm{Hb}(\mathrm{g} / \mathrm{dl})$ & $12.21 \pm 0.97$ & $8.25 \pm 2.37$ & $<0.001$ & $\begin{array}{l}\mathrm{r}=-0.791 \\
\mathrm{p}<0.001\end{array}$ \\
\hline $\mathrm{HCT}(\%)$ & $37.67 \pm 2.8$ & $24.46 \pm 6.62$ & $<0.001$ & $\begin{array}{l}\mathrm{r}=-0.790 \\
\mathrm{p}<0.001\end{array}$ \\
\hline $\mathrm{MCV}(\mathrm{fL})$ & $81.36 \pm 4.37$ & $87.69 \pm 11.58$ & $<0.01$ & $\begin{array}{l}\mathrm{r}=0.314 \\
\mathrm{p}<0.01\end{array}$ \\
\hline $\mathrm{MCH}(\mathrm{pg})$ & $26.42 \pm 1.93$ & $29.47 \pm 4.27$ & $<0.001$ & $\begin{array}{l}\mathrm{r}=0.379 \\
\mathrm{p}<0.001\end{array}$ \\
\hline $\mathrm{MCHC}(\mathrm{g} / \mathrm{dl})$ & $32.58 \pm 1.13$ & $33.67 \pm 1.99$ & $<0.01$ & $\begin{array}{l}\mathrm{r}=0.268 \\
\mathrm{p}=0.01\end{array}$ \\
\hline Leukocytes $\left(10^{3} / \mu \mathrm{l}\right)$ & $7.58 \pm 2.43$ & $12.18 \pm 9.85$ & $<0.01$ & $\begin{array}{l}\mathrm{r}=0.396 \\
\mathrm{p}<0.001\end{array}$ \\
\hline Lymphocytes $\left(10^{3} / \mu \mathrm{l}\right)$ & $3.48 \pm 1.2$ & $4.29 \pm 2.25$ & $<0.05$ & $\mathrm{NS}$ \\
\hline Monocytes $\left(10^{3} / \mu \mathrm{l}\right)$ & $0.37 \pm 0.14$ & $1.13 \pm 1.11$ & $<0.001$ & $\begin{array}{l}\mathrm{r}=0.640 \\
\mathrm{p}<0.001\end{array}$ \\
\hline Granulocytes $\left(10^{3} / \mu \mathrm{l}\right)$ & $3.72 \pm 1.99$ & $5.76 \pm 3.34$ & $<0.01$ & $\begin{array}{l}\mathrm{r}=0.357 \\
\mathrm{P}<0.01\end{array}$ \\
\hline
\end{tabular}

All data are presented as mean $\pm \mathrm{SD}$ (Sinificance $\mathrm{p}<0.05$, no significance (NS)

Coagulation function parameters' values; platelets count, international normalized ratio (INR), activated partial thromboplastin time (APTT) and thrombinantithrombin (TAT) were as shown in Table 3. A highly measured for patients and control subjects significant increase in each INR, PTT and TAT levels in SCD patients $(\mathrm{r}=0.565, \quad \mathrm{p}<0.00 ; \quad \mathrm{r}=0.741, \quad \mathrm{p}<0.001$; $\mathrm{r}=0.234, \mathrm{p}<0.05)$, respectively. Platelets count was insignificant among our both grou

Table 3. Coagulation parameters of SCD patients and control subjects.

\begin{tabular}{|l|l|l|l|l|}
\hline Parameter & Control $\mathrm{n}=41$ & SCD $\mathrm{n}=50$ & $\mathrm{p}$-value & Correlation with SCD \\
\hline Platelets $\left(10^{3} / \mu \mathrm{l}\right)$ & $310.58 \pm 82.53$ & $324.08 \pm 158.69$ & $\mathrm{NS}$ & $\mathrm{NS}$ \\
\hline INR & $1.032 \pm 0.034$ & $1.186 \pm 0.15$ & $<0.001$ & $\begin{array}{l}\mathrm{r}=0.565 \\
\mathrm{p}<0.001\end{array}$ \\
\hline PTT $(\mathrm{s})$ & $26.2 \pm 2.72$ & $33.71 \pm 7.16$ & $<0.001$ & $\begin{array}{l}\mathrm{r}=0.741 \\
\mathrm{p}<0.001\end{array}$ \\
\hline TAT $(\mathrm{ng} / \mathrm{l})$ & $21.19 \pm 20.14$ & $32.19 \pm 16.32$ & $<0.01$ & $\begin{array}{l}\mathrm{r}=0.234 \\
\mathrm{p}<0.01\end{array}$ \\
\hline
\end{tabular}

All data are presented as mean \pm SD (Significance $\mathrm{p}<0.05)$.

\section{DISCUSSION}

Sickle cell disease is characterized by a chronic inflammatory state(Platt, 2000; Hebbel et al., 2004). Patients exhibit elevated leukocyte counts, abnormal activation of granulocytes, monocytes, and endothelial cells(Soloveyet al., 1997; Belcher et al., 2000; Inwaldet al., 2000), and increased levels of multiple inflammatory mediators(Graido-Gonzalez et al., 1998; Hebbel et al., 2004; Pathareet al., 2004; Lee et al., 2006). In this study, 
we found an increase in all leukocytes count and their types; lymphocytes, monocytes and granulocytes in SCD patients compared to control subjects.

In addition, SCD is often referred to as a hypercoagulable state(Francis $\mathbf{J r}$, 1991) because patients manifest increased thrombin and fibrin generation(Westermanet al., 1999; Tomeret al., 2001)increased tissue factor procoagulant activity(Singh et al., 2012)and increased platelet activation(Inwaldet al., 2000; Tomeret al., 2001; Lee et al., 2006) even when they are in a non-crisis, steady state. Furthermore, thrombosis may contribute to the pathogenesis of several SCD-related complications. For example, stroke, caused by large vessel obstruction with superimposed thrombosis, often occurs in SCD patients (Prengleret al., 2002). Both pulmonary embolism and pregnancy-related venous thromboembolism appear to occur more commonly in SCD patients than in appropriate control patients(Jameset al., 2006; Stein et al., 2006). In our cohort, Plasma levels of TAT were shown to be increased in patients with SCD compared to the levels in healthy controls. May be as a result of hypercoagulable state represented in SCD patients a significant increase in INR and APPT values were detected.
Several factors, including abnormal red blood cell phospholipid membrane asymmetry, with increased expression of phosphatidylserine(Zwaal\&Schroit, 1997) and ischemia-reperfusion injury(Soloveyet al., 2004) appear to contribute to the hypercoagulability observed in SCD patients.Data suggest that type II phosphatidylserine red blood cells (highly phosphatidylserine-positive and including dense sickle cells) cause a 2-fold increase in endothelial tissue factor expression. This appears to be due to the increased hemolysis of these cells rather than to the physical interaction of type II phosphatidylserine red blood cells with the endothelium in patients with SCD(Settyet al., 2006). We found a reduction in RBCs count, $\mathrm{Hb}$ concentration and hematocrit level, increase in RBCs indices (MCV, $\mathrm{MCH}$ and $\mathrm{MCHC}$ ) in SCD patients compared

to our health subjects.

\section{CONCLUSION}

Egyptian children with sickle cell disease indeed exhibit a hypercoagulable state with increase of

thrombin generation factors.

\section{CONFLICT OF INTEREST}

Authors declare that no conflict of interest. 


\section{REFERENCES}

Artemenko, E. O., Yakimenko, A. O., Pichugin, A. V., Ataullakhanov, F. I., \&Panteleev, M. A. (2016). Calpaincontrolled detachment of major glycoproteins from the cytoskeleton regulates adhesive properties of activated phosphatidylserine-positive platelets. Biochemical Journal, 473(4), 435-448.

Belcher, J. D., Marker, P. H., Weber, J. P., Hebbel, R. P., \&Vercellotti, G. M. (2000). Activated monocytes in sickle cell disease: potential role in the activation of vascular endothelium and vaso-occlusion. Blood, 96(7), 2451-2459.

Elias, D. B. D., Rocha, L. B. D. S., Cavalcante, M. B., Pedrosa, A. M., Justino, I. C. B., \&Gonçalves, R. P. (2012). Correlation of low levels of nitrite and high levels of fetal hemoglobin in patients with sickle cell disease at baseline. Revistabrasileira de hematologia e hemoterapia, 34(4), 265-2 69.

Francis Jr, R. B. (1991). Platelets, coagulation, and fibrinolysis in sickle cell disease: their possible role in vascular occlusion. Blood Coagulation \& Fibrinolysis, 2(2), 341-354.

Graido-Gonzalez, E., Doherty, J. C., Bergreen, E. W., Organ, G., Telfer, M., \& McMillen, M. A. (1998). Plasma endothelin-1, cytokine, and prostaglandin E2levels in sickle cell disease and acute vaso-occlusive sickle crisis. Blood, 92(7), 2551-2555.

Hebbel, R. P., Osarogiagbon, R., \& Kaul, D. (2004). The endothelial biology of sickle cell disease: inflammation and a chronic vasculopathy. Microcirculation, 11(2), 129-151.

Inwald, D. P., Kirkham, F. J., Peters, M. J., Lane, R., Wade, A., Evans, J. P., \& Klein, N. J. (2000). Platelet and leucocyte activation in childhood sickle cell disease: association with nocturnal hypoxaemia. British journal of haematology, 111(2), 474-481.
James, A. H., Jamison, M. G., Brancazio, L. R., \& Myers, E. R. (2006). Venous thromboembolism during pregnancy and the postpartum period: incidence, risk factors, and mortality. American journal of obstetrics and gynecology, 194(5), 1311-1315.

Kato, G. J. (2015). Defective nitric oxide metabolism in sickle cell disease. Pediatr Blood Cancer, 62(3), 373-374.

Lee, S. P., Ataga, K. I., Orringer, E. P., Phillips, D. R., \& Parise, L. V. (2006). Biologically Active CD40 Ligand Is Elevated in Sickle Cell Anemia Potential Role for Platelet-Mediated Inflammation. Arteriosclerosis, thrombosis, and vascular biology, 26(7), 1626-1631.

Nishank, S. S., Singh, M. P. S. S., \& Yadav, R. (2013). Clinical impact of factor V Leiden, prothrombin G20210A, and MTHFR C677T mutations among sickle cell disease patients of Central India. European journal of haematology, 91(5), 462-466.

Pathare, A., Al Kindi, S., Alnaqdy, A. A., Daar, S., Knox-Macaulay, H., \& Dennison, D. (2004). Cytokine profile of sickle cell disease in Oman. American journal of hematology, 77(4), 323-328.

Platt, O. S. (2000). Sickle cell anemia as an inflammatory disease. The Journal of clinical investigation, 106(3), 337-338.

Prengler, M., Pavlakis, S. G., Prohovnik, I., \& Adams, R. J. (2002). Sickle cell disease: the neurological complications. Annals of neurology, 51(5), 543-552.

Setty, B. N. Y., Zhang, J., Kulkarni, S., Wang, X., Key, N. S., Gladwin, M. T., \& Stuart, M. J. (2006, April). Pathologic implications of type-II phosphatidylserine (PS)-positive erythrocytes in patients with sickle cell disease. In 29th Annual Meeting of the National Sickle Cell Disease Program (pp. 8-12).

Shet, A. S., Aras, O., Gupta, K., Hass, M. J., Rausch, D. J., Saba, N., \& Hebbel, R. P. (2003). Sickle blood contains tissue factor-positive microparticles 
derived from endothelial cells and monocytes. Blood, 102(7), 2678-2683.

Singh, A., Boden, G., Homko, C., Gunawardana, J., \& Rao, A. K. (2012). Whole-Blood Tissue Factor Procoagulant Activity Is Elevated in Type 1 Diabetes Effects of hyperglycemia and hyperinsulinemia. Diabetes care, 35(6), 1322-1327.

Solovey, A., Kollander, R., Shet, A., Milbauer, L. C., Choong, S., PanoskaltsisMortari, A., Blazar, B. R., Kelm, R. J., \& Hebbel, R. P. (2004). Endothelial cell expression of tissue factor in sickle mice is augmented by hypoxia/reoxygenation and inhibited by lovastatin. Blood, 104(3), 840846.

Solovey, A., Lin, Y., Browne, P., Choong, S., Wayner, E., \& Hebbel, R. P. (1997). Circulating activated endothelial cells in sickle cell anemia. New England Journal of Medicine, 337(22), 1584-1590. Stein, P. D., Beemath, A., Meyers, F. A., Skaf, E., \& Olson, R. E. (2006). Deep venous thrombosis and pulmonary embolism in hospitalized patients with sickle cell disease. The American journal of medicine, 119(10), 897-e 7.

Stowell, S. R., Karmakar, S., Arthur, C. M., Ju, T., Rodrigues, L. C., Riul, T. B.,
Dias-Baruffi, M., Miner, J., McEver R. P., \& Cummings, R. D. (2009). Galectin-1 induces reversible phosphatidylserine exposure at the plasma membrane. Molecular biology of the cell, 20(5), 14081418.

Tomer, A., Harker, L. A., Kasey, S., \&Eckman, J. R. (2001). Thrombogenesis in sickle cell disease. Journal of Laboratory and Clinical Medicine, 137(6), 398-407.

Uchida, Y., Hasegawa, J., Chinnapen, D., Inoue, T., Okazaki, S., Kato, R., Wakatsuki, S., Misaki, R., Koike, M., Uchiyama, Y. \&Iemura, S. I. (2011). Intracellular phosphatidylserine is essential for retrograde membrane traffic through endosomes. Proceedings of the National Academy of Sciences, 108(38),

\section{6-15851.}

Westerman, M. P., Green, D., Gilman-Sachs, A., Beaman, K., Freels, S., Boggio, L., Allen, S., Zuckerman, L., Schlegel, R., \& Williamson, P. (1999). Antiphospholipid antibodies, proteins $\mathrm{C}$ and $\mathrm{S}$, and coagulation changes in sickle Zwaal, R. F., \&Schroit, A. J. (1997). Pathophysiologic implications of membrane phospholipid asymmetry in blood cells. Blood, 89(4), 1121-1132. 